\title{
THE INFLUENCE OF SMOKE LIQUID OF COCONUT SHELL ON PLAQUE INDEX
}

\section{Wiworo Haryani ${ }^{{ }^{*}}$}

\begin{abstract}
ABSTRAK
Ekstrak tempurung kelapa memiliki kandungan antioksidan dan sifat antibakterial yang sangat tinggi. Kandungan ini tentunya dapat berpengaruh bakteri oral terutama yang terdapat di dalam plak gigi. Ekstrak tempurung kelapa ini dalam bentuk cairan yang diperoleh melalui sistem pengasapan. Tujuan penelitian ini untuk mengetahui pengaruh berkumur menggunakan ekstrak tempurung kelapa dalam bentuk asap cair dengan beberapa konsentrasi terhadap keberadaaan plak gigi.

Jenis penelitian ini adalah quasi experiment. Rancangan dalam penelitian ini adalah pre-post experiment. Adapun cara pengambilan sampel yaitu dengan cara Simple Random Sampling, menggunakan seluruh mahasiswa Jurusan Keperawatan Gigi mulai dari tingkat 1, 2, dan 3 maka sampel yang akan diambil adalah $10 \%$ dari total mahasiswa sejumlah 24 orang dengan pengambilan sampel secara acak sederhana. Data dianalisis menggunakan uji Anova.

Hasil penelitian menunjukan penggunaan larutan ini sebagai obat kumur ternyata memberikan pengaruh signifikan antara sebelum dan sesudah berkumur pada masing-masing kelompok konsentrasi larutan ( $p$ value 0,017; 0,001; 0,000 < 0,005). Peningkatan konsentrasi juga berpengaruh signifikan terhadap penurunan plak indeks ( $p$ value 0,015 <0,005). Perlu dilakukan penelitian lanjutan terkait dengan pengaruh konsetrasi larutan asap cair terhadap bakteri-bakteri yang ada di dalam rongga mulut.
\end{abstract}

Kata kunci : Asap cair, tempurung kelapa, plak

\begin{abstract}
Coconut shell contains high antioxidant an anti bacterial agent which could influence oral bacterial growth in dental plaque. The extract - known as liquid smoke - is the vinegar of biomass pyrolysis process. This study wanted to know the influence of mouth rinsing using liquid smoke of coconut shell toward dental plaque's existence.

This study was used the quasi-experiment method. The design of this study was a pre-post the experiment. The samples were randomized on JKG's students which were 24 students. The data were analyzed Anova Test.

The result showed that there wasa significant influence before and after mouth rinsing with liquid smoke ( $p$-value 0.017; 0.001; $0.000<0.005$ ) in each group. The increase of the concentration of liquid smoke had a significant influence on the decrease of plaque index ( $p$-value $0.015<0.005)$. It's suggested that this research had to be continued to find out the influence of the concentrations of smoke liquid on oral bacteria.
\end{abstract}

Keywords : Liquid smoke, coconut shell, dental plaque

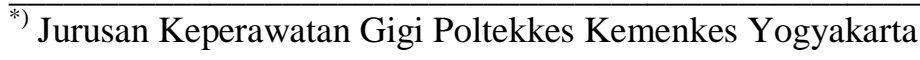

: haryaniwiworo@gmail.com 


\section{PENDAHULUAN}

Kesehatan gigi merupakan masalah nasional. Menurut data Riset Kesehatan Dasar (Riskesdas) (Kemenkes, 2013), sebanyak 25,9 persen masyarakat Indonesia mengalami masalah kesehatan gigi. Data juga menunjukkan indeks DMF-T mencapai 4,6 yang mengindikasikan 460 kerusakan gigi pada 100 orang. Proses karies diawali dengan proses dekalsifikasi akibat metabolisme bakteri yang terakumulasi dalam dental plak yaitu lapisan mikrobiofilm yang terdapat pada permukaan gigi. Dalam 1 $\mathrm{mm}^{3}$ plak gigi atau seberat $1 \mathrm{mg}$ terdapat lebih dari $10^{8}$ bakteri (Lindhe dkk, 2008).

Salah satu alternatif solusi mencegah pertubuhan bakteri adalah dengan menggosok gigi dan menggunakan obat kumur. Obat kumur yang beredar saat ini mengandung banyak zat-zat kimia yang terkadang menimbulkan reaksi alergi. Penggunaan obat kumur herbal merupakan alternatif terbaik karena selain harganya relatif murah dan lebih aman serta sangat jarang menimbulkan reaksi aleri. Asap cair dari tempurung kelapa disamping digunakan sebagai bahan pengawet makanan, ternyata juga mengandung komponen-komponen seperti fenol, asam organik dan karbonil yang berfungsi sebagai antibakteri, antijamur dan koagulan (Girrard, 1992). Asap cair merupakan hasil dari dekomposisi selulosa, hemiselulosa dan lignin melalui proses pirolisis. Penghilangan air dari kayu pada suhu $120-150^{\circ} \mathrm{C}$, pirolisa hemiselulosa pada suhu $200-250^{\circ} \mathrm{C}$, pirolisa selulosa pada suhu $280-320^{\circ} \mathrm{C}$ dan pirolisa lignin pada suhu $400^{\circ} \mathrm{C}$.

Budijanto dkk (2008) telah menganalisa asap cair tempurung kelapa menggunakan GCMS terdapat 40 komponen dengan dengan 7 komponen yang dominan yaitu 2-Methoxyphenol (guaiacol), 3,4Dimethoxyphenol, Phenol, 2-methoxy-4 methylphenol, 4-Ethyl-2-methoxyphenol, 3Methylphenol, dan 5-Methyl-1,2,3trimethoxybenzene. Selain itu, tidak ditemukan adanya senyawa-senyawa
Policyclic Aromatic Hydrocarbon (PAH) yang bersifat karsinogenik termasuk benzo[a]pyrene dalam asap cair tempurung kelapa.

Sedangkan Luditama (2006) mengidentifikasi 26 senyawa dengan senyawa dominan fenol $(34,45 \%)$, 2,6dimethoxy fenol $(12,58 \%)$ dan 2-methoxy fenol $(9,81 \%)$. Ekstraksi menggunakan berbagai pelarut akan menghasilkan komponen polifenol yang berbeda pula. Sifat antibakteri yang dimiliki oleh setiap senyawa yang diperoleh dari ekstraksi tersebut juga berbeda. Ekstraksi suatu bahan pada prinsipnya dipengaruhi oleh suhu. Makin tinggi suhu yang digunakan, makin tinggi ekstrak yang diperoleh. Melalui proses pirolisis dengan pemanasan sampai $400{ }^{\circ} \mathrm{C}$, tentunya ekstrak fenol yang diperoleh mempiliki kemampuan antibakteri yang cukup tinggi.

Tujuan penelitian ini dilakukan adalah untuk mengetahui pengaruh berkumur menggunakan ekstrak tempurung kelapa dalam bentuk asap cair dengan beberapa konsentrasi terhadap keberadaaan plak gigi.

\section{METODE PENELITIAN}

Penelitian ini menggunakan jenis penelitian semu atau pura-pura (quasy experiment) yaitu suatu penelitian dengan melakukan kegiatan percobaan yang bertujuan untuk mengetahui suatu gejala atau pengaruh yang timbul sebagai akibat tanpa adanya kelompok kontrol. Jumlah sampel dalam penelitian ini adalah 24 mahasiswa Jurusan Keperawatan Gigi yang dipilih secara random (acak) yang dibagi dalam 3 kelompok. Sampel tersebut disamakan kondisinya dengan menggosok gigi selama 2 menit dan tidak boleh makan maupun minum selama 5 menit sebelum dilakukan intervensi berkumur larutan asap cair.

Ekstrak asap cair tempurung kelapa yang digunakan dibeli di toko bahan kimia yang sudah diproses melalui proses pirolisis dan destilasi. Proses pirolisis merupakan 
proses pemanasan tempurung kelapa dalam reaktor pirolisis pada suhu $300^{\circ} \mathrm{C}, 400^{\circ} \mathrm{C}$, $500^{\circ} \mathrm{C}$. Hasilnya berupa produk cair dan gas. Produk hasil pirolisis tersebut selanjutnya didestilasi untuk memisahkan senyawa berbahaya dalam asap cair tersebut. Estrak asap cair tersebut dikonversikan menjadi larutan asap cair dengan konsentrasi 5\%, $10 \%$ dan $15 \%$.

Selanjutnya dilakukan tindakan intervensi terhadap ketiga kelompok sampel sebagai berikut :

1. Setelah tahap persiapan sampel, dilakukan pengukuran plak indeks dari masingmasing sampel

2. Lalu tiap kelompok diberikan larutan kumur asap cair @20 ml dengan konsentrasi yang berbeda yaitu 5\%, 10\% dan $15 \%$.

3. Sampel berkumur selama 30 detik dan dibuang. Stelah berkumur, sampel beristirahat 5 menit tanpa makan, minum maupun berkumur

4. Selanjutnya sampel dihitung plak indeksnya kembali

\section{HASIL DAN PEMBAHASAN}

\section{$\underline{\text { Uji Univariat }}$}

Tabel 1. Distribusi Plak Indeks Sebelum dan Sesudah Berkumur Asap Cair

\begin{tabular}{lccccc}
\hline \multicolumn{1}{c}{ Larutan } & Waktu & $\mathrm{N}$ & Min & Max & Selisih \\
\hline Ekstrak tempurung & Sebelum & 8 & 1.0 & 2.3 & 0,250 \\
kelapa 5\% & Sesudah & 8 & .8 & 1.8 & \\
Ekstrak tempurung & Sebelum & 8 & .3 & 1.6 & 0,350 \\
kelapa 10\% & Sesudah & 8 & .2 & 1.3 & \\
Ekstrak tempurung & Sebelum & 8 & .6 & 1.5 & 0,387 \\
kelapa 15\% & Sesudah & 8 & .1 & 1.1 & \\
\hline
\end{tabular}

Berdasarkan Tabel 1 terlihat bahwa ada penurunan plak Indeks antara sebelum dan sesudah berkumur asap cair pada masing-masing konsentrasi. Disamping itu, penurunan plak indeks terjadi seiring dengan peningkatan konsentrasi larutan asap cair.

\section{$\underline{\text { Uji Bivariat }}$}

Analisis bivariat adalah analisa untuk menguji ada atau tidaknya pengaruh antara variabel dependen dan independen. Analisa ini digunakan untuk mendiskripsikan distribusi data, meguji perbedaan dan mengukur hubungan antara dua variabel yang diteliti.

Tabel 2. Uji Normalitas data Shapiro Wilk

\begin{tabular}{|c|c|c|c|c|}
\hline \multirow{2}{*}{ Perlakuan } & \multicolumn{3}{|c|}{ Shapiro-Wilk } & \multirow{2}{*}{ Keterangan } \\
\hline & Statistik & Df & Sig. & \\
\hline $\begin{array}{l}\text { Plak Indeks Sebelum } \\
\text { Berkumur 5\% asap cair }\end{array}$ & 0,771 & 8 & 0,014 & $\begin{array}{c}\text { Tidak } \\
\text { normal }\end{array}$ \\
\hline $\begin{array}{l}\text { Plak Indeks Setelah } \\
\text { Berkumur } 5 \% \text { asap cair }\end{array}$ & 0,725 & 8 & 0,004 & $\begin{array}{l}\text { Tidak } \\
\text { normal }\end{array}$ \\
\hline $\begin{array}{l}\text { Plak Indeks Sebelum } \\
\text { Berkumur } 10 \% \text { asap } \\
\text { cair }\end{array}$ & 0,918 & 8 & 0,410 & Normal \\
\hline $\begin{array}{l}\text { Plak Indeks Setelah } \\
\text { Berkumur } 10 \% \text { asap } \\
\text { cair }\end{array}$ & 0,827 & 8 & 0,056 & Normal \\
\hline $\begin{array}{l}\text { Plak Indeks Sebelum } \\
\text { Berkumur } 15 \% \text { asap } \\
\text { cair }\end{array}$ & 0,923 & 8 & 0,456 & Normal \\
\hline $\begin{array}{l}\text { Plak Indeks Setelah } \\
\text { Berkumur } 15 \% \text { asap } \\
\text { cair }\end{array}$ & 0,941 & 8 & 0,620 & Normal \\
\hline
\end{tabular}

Berdasarkan Tabel 2 terlihat bahwa distribusi data tidak normal terjadi pada plak indek sebelum dan setelah berkumur 5\% asap cair ( $\mathrm{p}$ value $<0,005)$ sehingga dilakukan uji bivariat Wilcoxon.

Uji Wilcoxon digunakan untuk menganalisis hasil-hasil pengamatan yang berpasangan dari dua data apakah berbeda atau tidak. Wilcoxon signed Rank test ini digunakan hanya untuk data bertipe interval atau ratio yang tidak distribusi normal. Berdasarkan uji Wilcoxon terlihat ada perbedaan yang signifikan pada masingmasing kelompok sebelum dan sesudah berkumur asap cair berkonsentrasi 5\%. 10\% dan 15\%. Dapat dilihat pada tabel berikut ini: 
Tabel 3. Perbedaan Plak Indeks Sebelum dan Sesudah Berkumur Asap Cair

\begin{tabular}{lllllll}
\hline \multicolumn{1}{c}{ Larutan } & Waktu & $\mathrm{N}$ & Mean \pm SD & $\begin{array}{c}p \text { - } \\
\text { value }\end{array}$ & Keterangan \\
\hline $\begin{array}{l}\text { Ekstrak } \\
\text { tempurung } \\
\text { kelapa 5\% }\end{array}$ & $\begin{array}{l}\text { Sebelum } \\
\text { Sesudah }\end{array}$ & 8 & $1.338 \pm 0.4241$ & $1.088 \pm 0.3044$ & 0,017 & Signifikan \\
$\begin{array}{l}\text { Ekstrak } \\
\text { tempurung }\end{array}$ & Sebelum & 8 & $1.050 \pm 0.4309$ & 0,001 & Signifikan \\
kelapa 10\% & Sesudah & 8 & $0.700 \pm 0.3423$ & & & \\
$\begin{array}{l}\text { Ekstrak } \\
\text { tempurung }\end{array}$ & Sebelum & 8 & $0.975 \pm 0.3423$ & 0,000 & Signifikan \\
kelapa 15\% & Sesudah & 8 & $0.588 \pm 0.3357$ & & \\
\hline
\end{tabular}

\section{Uji Multivariat}

Uji Anova merupakan analisis statistik yang menguji perbedaan rerata kelompok atau jenis perlakuan pada lebih dari 2 kelompok sampel. Dari Tabel 4 terlihat adanya perbedaan yang signifikan dari ketiga kelompok intervensi dimana $p$ value $0,015<0,05$.

Tabel 4. Hasil Uji Anova Plak Indek antar Kelompok Intervensi

\begin{tabular}{lccccc}
\hline & $\begin{array}{c}\text { Sum of } \\
\text { Squares }\end{array}$ & df & $\begin{array}{c}\text { Mean } \\
\text { Square }\end{array}$ & F & Sig. \\
\hline Between Groups & 1,101 & 2 & 0,550 & 5,120 & 0,015 \\
Within Groups & 2,258 & 21 & 0,108 & & \\
\hline Total & 3,358 & 23 & & & \\
\hline
\end{tabular}

Hasil penelitian ini menunjukkan bahwa asap cair tempurung kelapa memberikan pengaruh yang signifikan terhadap keberadaan plak indeks. Kemampuan antibakteri yang terdapat di dalam kandungan asap cair tersebut juga berdampak pada bakteri rongga mulut yang terakumulasi dalam plak gigi. Dominasi Fenol sebagai antibakteri bersifat meracuni protoplasma, merusak dan menembus dinding serta mengendapkan protein sel bakteri. Senyawa fenol dalam konsentrasi yang sangat rendah mampu menyebabkan kebocoran metabolit penting dan menginaktifkan enzim esensial di dalam sel bakteri (Madigan, 2005).
Pada hasil penelitian terlihat pula bahwa semakin tinggi konsentrasi larutan asap cair ini, semakin rendah pula plak indeks yang terlihat. Artinya, semakin tinggi konsentrasi larutan asap cair ini, maka reaksi antibakterinya juga akan semakin tinggi dan akumulasi bakteri dalam plak gigi dapat diturunkan. Menurut Pratama (2011), salah satu faktor yang dapat mempengaruhi daya antibakteri yaitu konsentrasi zat antibakteri, semakin tinggi konsentrasi semakin banyak jumlah bakteri yang terbunuh.

Kandungan lain yang terdapat dalam asap cair ini adalah asam asetat yang merupakan asam organik yang aman sebagai zat preservasi dan tidak ada batas penggunaannya. Asam Laktat merupakan dasar biologi dari banyak makanan fermentasi. Asam laktat dapat menghasilkan senyawa antimikroba seperti asam organik (laktat, sitrat, dan lain-lain), diasetil, karbon dioksida, hidrogen peroksida dan bakteriosin (Diop dkk, 2007). Menurut Suprapto dan Dian (2006), penggunaan asam asetat dalam jangka waktu lama tidak membahayakan kesehatan karena dapat dimetabolisir oleh tubuh dan dieksresikan.

\section{KESIMPULAN}

Larutan asap cair tempurung kelapa memiliki daya anti bakteri yang dapat berpengaruh terhadap bakteri rongga mulut dalam plak gigi. Penggunaan larutan ini sebagai obat kumur ternyata memberikan pengaruh signifikan antara sebelum dan sesudah berkumur pada masing-masing kelompok konsentrasi larutan ( $p$ value 0,017 ; $0,001 ; 0,000)$. Peningkatan konsentrasi juga berpengaruh signifikan terhadap penurunan plak indeks ( $p$ value 0,015$)$.

\section{SARAN}

Perlu dilakukan penelitian lanjutan terkait dengan pengaruh konsentrasi larutan asap cair terhadap bakteri-bakteri yang ada di dalam rongga mulut. 


\section{DAFTAR PUSTAKA}

Budijanto, S., Hasbullah, R., Prabawati, S., Setyadjit, Sukarno dan Zuraida, I., 2008. Identifikasi dan Uji Keamanan Asap Cair Tempurung Kelapa Untuk Produk Pangan. J. Pascapanen. Vol. 5 No. 1. Hal. 32-40.

Diop MB, Dubois-Dauphin R, Tine E, Ngom A, Destain J, Thonart P. 2007. Bacteriocin producers from traditional food products. Biotechnol Agron Soc Environ 11: 275-281.

Gani, A., 2007. Konversi Sampah Organik Pasar Menjadi Komarasca (KomposArang Aktif-Asap Cair) dan Aplikasinya pada Tanaman Daun Dewa. Thesis. Sekolah Pascasarjana, Institut Pertanian Bogor. Bogor.

Girrard, J.P., 1992, Technology of Meat and Meat Products, Ellis Horwood, New York.

Kemenkes RI, 2013, Badan Penelitian dan Pengembangan Kesehatan, Riskedas

Lindhe J, Karring T, Lang NP. Clinical Periodontology and Implant Dentistry. Blackwell Munksgaard Oxford, 5th ed. 2008, p. 183.

Luditama, Candra. 2006. Isolasi dan Pemurnian Asap Cair Berbahan Dasar Tempurung dan Sabut Kelapa Secara Pirolisis dan Distilasi. Skripsi. Fakultas Teknologi Pertanian, Institut Pertanian Bogor. Bogor.

Madigan M.2005. Brock Biology of Microorganisme. $\mathrm{p}$ :753. London: PrenticeHall.

$\begin{array}{crr}\text { Pratama, A. 2011. } & \text { Pengaruh } & \text { Perbedaan } \\ \text { Konsentrasi } & \text { ekstrak } & \text { Etanolik } \\ \text { Propolis 20\%, } 30 \%, & \text { dan } 40 \% \\ \text { terhadap } & \text { Daya } & \text { Hambat }\end{array}$

porphyromonas gingivalis (kajian in vitro). [serial on line].http://drgadipratama.blogspot.co $\underline{\mathrm{m} / 2012 / 12 / \text { pengaruhperbedaan- }}$ konsentrasi-ekstrak_11.html. $[15$ Januari2013].

Suprapto dan Dian. 2006. Salmonella bahaya tak terlihat dan mengenal foodborne disease.

http://www.Charisma.de/?=node/176. 